\title{
Fenetheylline in the Middle East, a thriving trade in the post-Saddam era
}

\author{
Ahmed M Lutfi ${ }^{1,2}$ \\ ${ }^{1}$ Doctorate Student (PhD), School of Life and Medical Sciences, University of Hertfordshire, Hatfield, United Kingdom, \\ ${ }^{2}$ Lecturer \& Researcher, Faculty of Medicine, University of Baghdad, Iraq
}

Aims and Objectives: To collect up-to-date knowledge using a systematic review of the literature and to get evidence-based data concerning Fenethylline, and its illegal commerce in the region of the Middle East after 2003. Materials and Methods: Four main medical literature databases were scrutinized using a list of pre-specified keywords. Additionally, social networks, and other resources were utilized to retrieve relevant data. The total number of references that were used in this paper is twenty-two. Results: The literature search was conducted from the $3^{\text {rd }}$ of December to the $29^{\text {th }}$ of December 2015. The search was done from Baghdad, Iraq via the Earth link-Telenet Internet Service Provider (ISP). The Total Search Engine Results Pages (SERPs) were 463137. The highest SERPs were for the keywords "Amphetamine" and "Fitton." Google Scholar and PubMed were the databases that scored the highest SERPs. Captagon is a dangerous psychoactive substance. Its production was officially stopped in the 1980s. Currently, Captagon, and counterfeit Captagonare being illegally produced in South-East Europe and trafficked to the region of the Middle East. Conclusion: In the post-Saddam era of the Middle East, this substance has been traded and distributed at an exponential rate. The main explanation is that the rise of this illegal commerce is related to the chaos and the lack of order in the regions of conflict and civil war in Syria and Iraq in particular.

\section{Access this article online}

Website:

http://nepjol.info/index.php/AJMS

DOI: $10.3126 /$ ajms.v7i4.14228

E-ISSN: 2091-0576

P-ISSN: 2467-9100

Key words: Fenethylline, Captagon, Amphetamines, PIEDs, Psychoactive, Illicit

\section{INTRODUCTION}

Performance and Imaging Enhancing Drugs (PIEDs) is a term utilized for the description of all existing forms of substances, natural or synthetic, that can enhance the image of an individual, their physiologic performance, or both. Fenethylline, also known by the brand name "Captagon", is a PIED. It best fit as a performance enhancer and a psychostimulant. Additionally, it is a potential hallucinogenic and epileptogenic agent. The chemical formula of the drug is $\mathrm{C}_{18} \mathrm{H}_{23} \mathrm{~N}_{5} \mathrm{O}_{2}$. In 1981, it was listed as a schedule I substance in the United States, and it became illegal in most countries in 1986 after being listed by the World Health Organization for international scheduling under the Convention on Psychotropic Substances. ${ }^{1-3}$

\section{MATERIALS AND METHODS}

To collect the data of the best quality and the highest amount of available evidence in the literature, four essential medical literature databases were searched. These were: Google Scholar, PubMed, the Cochrane Library, and Open Grey. Ten keywords were utilized across these databases (Table 1 and Figure 1) to generate Search Engine Results Pages (SERPs).

This literature search was conducted from the $3^{\text {rd }}$ of December to the $29^{\text {th }}$ of December 2015. The search was done from Baghdad, Iraq via the Earthlink-Telenet Internet Service Provider (ISP). The total SERPs for the search were 463137. The highest SERPs were for the keywords "Amphetamine" and "Fitton," as seen in 


\begin{tabular}{lccccc} 
Table 1: Keywords versus database results & & & \\
\hline Keyword vs. database & Google scholar & PubMed & Cochrane library & OpenGrey & Total \\
\hline Captagon & 663 & 39 & 1 & 0 & 703 \\
"01 pills" & 16 & 371 & 0 & 1 & 388 \\
Fenethylline & 518 & 32 & 1 & 0 & 552 \\
"Counterfeit Captagon" & 25 & 5 & 0 & 0 & 26 \\
"Counterfeit Amphetamine" & 3 & 125 & 0 & 0 & 8 \\
"Inferior Amphetamine" & 0 & 42187 & 9208 & 80 & 417475 \\
Amphetamine & 366000 & 32 & 1 & 19 & 35 \\
Biocapton & 3 & 305 & 9211 & 101 & 43825 \\
Fitton & 43500 & 43097 & & 463137 \\
Total & 410728 & & & & 101 \\
\hline
\end{tabular}

Figure 1. Google Scholar and PubMed were the databases that scored the highest SERPs.

The most relevant and up-to-date papers were used for referencing this paper. The total number of references is twenty-two. These were gathered from medical literature databases, paramedical databases, social networks, and others.

\section{RESULTS AND DISCUSSION}

Fenethylline is used in medicine as a psychostimulant under the brand names Captagon, Biocapton and Fitton. It is rumored that it can turn ordinary men into supersoldiers. However, Captagon is considered an "inferior amphetamine," with an effect milder than Adderall. It is made of a combination of theophylline and amphetamine. Theophylline is a respiratory system enhancer, acting mainly by opening the airways. Amphetamine is the main psychoactive ingredient. It was used in the 1960s and 1970s to treat people with attention deficit disorder (ADD). Captagon can produce feelings of pleasure (euphoria) and increased alertness and a reduced need for sleep or even food. Captagon substance abuse has been a major problem in Saudi Arabia for over a decade, especially for the 12-22 age group, and 40 percent of all Saudi drug addicts are Captagon addicts. ${ }^{3-7}$

Islamic State fighters, currently known as ISIS or ISIL, are being fueled by a black market of amphetamine supplements. A 19-year-old ISIS fighter, in an interview with the CNN, said "They gave us drugs, hallucinogenic pills that would make you go to battle not caring if you live or die." Dr. Robert Keisling, a psychiatrist at MedStar Washington Hospital Center, said, "It gives you a sense of well-being and euphoria and you think that you're invincible and that nothing can harm you."Captagon trade in the Middle East, Arabian Gulf region, and the north of Africa is considered a prolific illegal trade with a high profit margin. Additionally, Captagon is not expensive to produce, and the demand is extremely high. The nature of the psychoactive ingredients in such tablets (Captagon powder also exists)

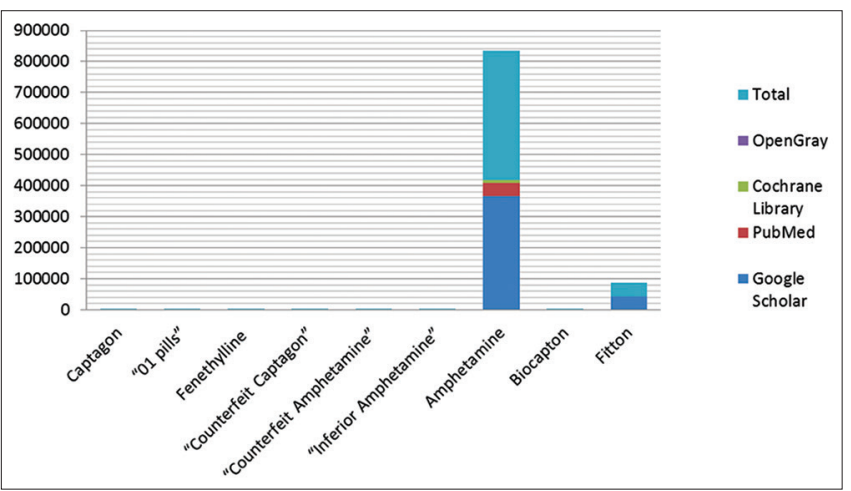

Figure 1: Keywords versus database results

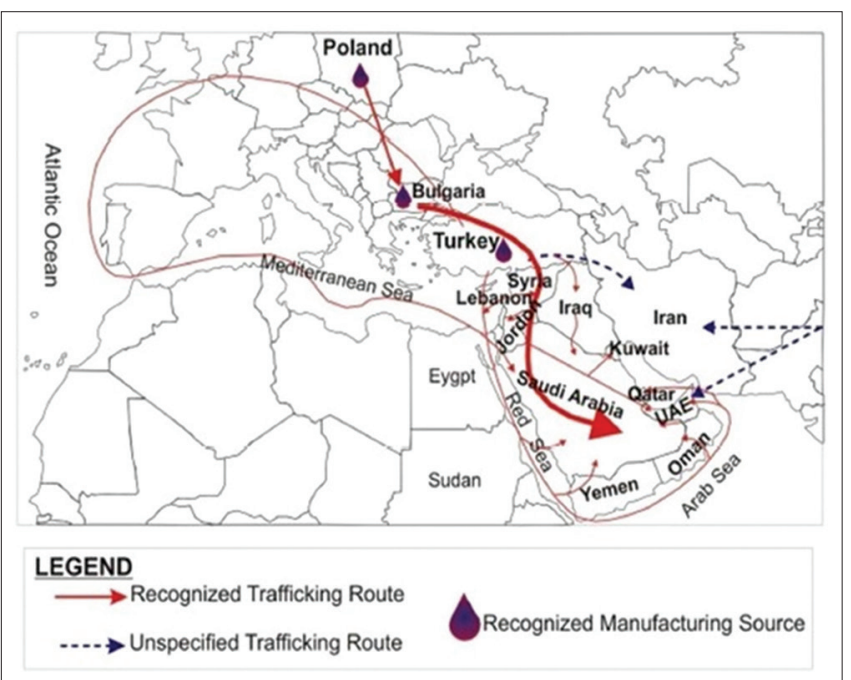

Figure 2: A map showing the countries that manufacture Captagon and its trafficking routes ${ }^{13}$

is not always clear. Counterfeit Captagon is usually more harmful, as it is not manufactured to meet any quality standards, and it may contain toxic substances (Table 2). Reports suggest that amphetamines trafficked from SouthEast Europe (Figure 2) are the main ingredients in Captagon tablets found in the Middle East (notably Saudi Arabia). Additionally, Southeast Asia is now the world's largest amphetamine-type stimulant (ATS) producer. According to leaks, military extremist groups, including ISIS, may export the drug in exchange for weapons or cash. ${ }^{8-15}$ 


\begin{tabular}{ll}
$\begin{array}{l}\text { Table 2: Ingredients of counterfeit } \\
\text { analyzed via gas chromatography in Jordan } \\
\text { in } 2005\end{array}$ \\
\hline Substance & Effect \\
\hline Amphetamine & Stimulant \\
Methamphetamine & Stimulant \\
Ephedrine & Sympathomimetic \\
Metronidazole & Anti-amebic \\
Caffeine & Stimulant \\
Theophylline & Vasodilator \\
Chlorphenamine & Anti-histamine \\
Procaine & Local anesthetic \\
Trimethoprim & Antibiotic \\
Chloroquine & Anti-malarial \\
Quinine & Anti-malarial \\
\hline Surprisingly, Fenethylline was absent, but other types of amphetamines were \\
present ${ }^{14}$
\end{tabular}

Over the last two decades in the Arabian Gulf states, illicit drugs have emerged as a growing social problem. Dubai is not an exception, and in spite of the growth of this dangerous phenomenon, the authorities have failed to respond adequately. Captagon is most commonly seized in countries such as Syria, Jordan, Kuwait, Qatar, and Saudi Arabia. As the current civil war in Syria has continued for over three years now, illicit economic activity is thriving, especially for PIEDs' commerce, including that of Captagon. Captagon-producing laboratories were found in Turkey until 2007. Its production has revealed that the manufacturers have moved to Syria. Currently, amphetamines are mostly produced (in the form of pills and powder) in Syria, Turkey, and Jordan. In Iraq, the drug-use scene includes amphetamine-type substances (ATS), including Captagon and crystal methamphetamine, and the painkiller tramadol. Seizures related to Captagon use indicate that these substances are becoming widely used at an exponential rate. The seizure reports estimate an expansion of the amphetamine and ATS market in Iraq. The first seizure from Captagon tablets was documented in 2009. Since that time, Captagon seizures have increased substantially. In the post-Saddam era in Iraq, the Iraqi law enforcement agencies were able to seize increasing amounts of Captagon and other ATS forms. For instance, Iraqi highway patrolmen seized around $200 \mathrm{~kg}$ of ATS in 2008. On another occasion, the Iraqi police seized 1.6 tons of amphetaminesin $2010 .^{16-22}$

\section{CONCLUSION}

Captagon is a dangerous psychoactive substance that can be addictive. It can affect the body physiology and induces particular disturbances of the nervous and the cardiovascular system. The substance's legal production was discontinued in the 1980s. However, illegal commerce thrived later. Currently, Captagon is being produced in South-East Europe and trafficked to the Middle East.
This substance is being highly utilized by consumers in Saudi Arabia. Additionally, in the post-Saddam era of the Middle East (after 2003), this substance has been traded and distributed at an exponential and alarming rate in Syria and Iraq. The main explanation is that the rise in the illegal commerce of such an illicit drug is related to the lack of order and a proper law system in the regions of conflict and civil war in Syria and Iraq in particular.

\section{ACKNOWLEDGEMENTS}

None.

\section{FINANCIAL DISCLOSURE}

Ahmed Al-Imam, the sole author of this paper, has no financial interests related to the material in the manuscript. No grants or external funding exist, this work on this study is completely self-funded.

\section{REFERENCES}

1. Corazza O, Valeriani G, Bersani FS, Corkery J, Martinotti G, Bersani G, etal. "Spice," "Kryptonite," "Black Mamba”: An overview of brand names and marketing strategies of novel psychoactive substances on the web. J Psychoactive Drugs 2014; 46:287-294.

2. Corazza O, Assi S, Simonato P, Corkery J, Bersani FS, Demetrovics Z, et al. Promoting innovation and excellence to face the rapid diffusion of novel Psychoactive substances in the EU: the outcomes of the reDNet project. Human Psychopharmacology: Clinical and Experimental 2013;28(4):317-323.

3. Fenethylline. Wikipedia, the free encyclopedia. [online] [cited 2015 December 29] Available from: URL: https://en.wikipedia. org/wiki/Fenethylline\#/media/File: Fenethylline.svg.

4. Miller S. A Pill for ISIS supersoldiers? Not so fast [online] 2015 [cited 2015 December 29]. Available from: URL: http://www. livescience.com/52904-captagon-amphetamine-pill-explainer. html.

5. $40 \%$ of young Saudi drug addicts taking Captagon [online] 2015 [cited 2015 December 29]. Available from: URL: http://www. arabnews.com/saudi-arabia/news/826906.

6. Dictionary of Organic Compounds. CRC Press.

7. Index Nominum 2000: International Drug Directory. Taylor \& Francis, 2000.

8. McConnell D and Todd B. Syria fighters may be fueled by amphetamines [online] 2015 [cited 2015 December 29] Available from: URL: http://edition.cnn.com/2015/11/20/world/ syria-fighters-amphetamine.

9. Middle East and North Africa. [online] [cited 2015 December 29]. Available from: URL: https://www.unodc.org/unodc/en/drugtrafficking/middle-east-and-north-africa.html.

10. Freeman C (12 January 2014). Syria's civil war being fought with fighters high ondrugs [online]2014 [cited 2015December 29]. Available from: URL: http://www.telegraph.co.uk/news/ worldnews/middleeast/syria/10567021/Syrias-civil-war-beingfought-with-fighters-high-on-drugs.html.

11. Kalin S. Insight:WarturnsSyriaintomajoramphetaminesproducer, consumer [online]2014[cited 2015December 29]. Available from: 
URL: http://www.telegraph.co.uk/news/worldnews/middleeast/ syria/10567021/Syrias-civil-war-being-fought-with-fighters-highon-drugs.html.

12. Available at: http://www.abc.net/news/2015-11-24/captagonthe-drug-that-kept-the-paris-attackers-calm/6970464. Accessed December 29, 2015.

13. Rahim BEA, Yagoub U, Mahfouz MS, Solan YMH and Alsanosi R. Abuse of selected psychoactive stimulants: Overview and future research trends. Life Sci J 2012; 9: 2295-2308.

14. Alabdalla MA. Chemical characterization of counterfeit Captagon tablets seized in Jordan. Forensic Sci Int 2005; 152:185-188.

15. Gao H. Drug Abuse and Drug Trafficking in Asia. In: Handbook of Asian Criminology. New York: Springer, 2013, pp 115-127.

16. Al-hemiary NJ, Al-diwan JK, Hasson $\mathrm{AL}$ and Rawson RA Drug and alcohol use in Iraq: Findings of the inaugural Iraqi Community Epidemiological Workgroup. Subst Use Misuse
2014;49:1759-1763.

17. Herbert M. Partisans, Profiteers, and Criminals: Syria's Illicit Economy. Fletcher F. World Aff 2014; 38:69.

18. Robins P. Narcotic Drugs in Dubai: Lurking in the Shadows. Br J Middle East Stud 2014;41:151-166.

19. Arslan M, Mustafa CZ, Celikel A, Ortanca I and Demirkiran S. Increased drug seizures in Hatay, Turkey related to civil war in Syria. Int J Drug Policy 2015; 26:116-118.

20. Çevik K. Internationalisation of Turkish law enforcement: A study of anti-drug trafficking [dissertation].Univ. of Nottingham, 2013.

21. Al-Ghafri H. Social Drift in Patients Suffering from Alcohol and Substance Related Disorders, Amman, Jordan. Int J Emerg Ment Health 2015.

22. Behsat E. Illicit Trans-border Trade between Iraq and Turkey in the post-Saddam Era. J Int Relat 2011.

Authors Contribution:

Ahmed Al-Imam - The sole author of this paper, was responsible for: Concept and design of the study, Data collection, Data interpretation, Literature review and critical revision of the manuscript.

Source of Support: Nil. Conflict of Interest: None. 